\title{
Ustvarjanje trajnostne prihodnosti
}

\author{
Polona Prosen* \\ Fakulteta za organizacijske študije v Novem mestu, Ulica talcev 3, 8000 Novo mesto, \\ Slovenija \\ polona.prosen@fos-unm.si
}

\section{Janja Gornik}

Fakulteta za organizacijske študije v Novem mestu, Ulica talcev 3, 8000 Novo mesto, Slovenija

janja.gornik@fos-unm.si

\begin{abstract}
Povzetek:
Raziskovalno vprašanje (RV): $\mathrm{V}$ raziskavi smo si s pomočjo izbranih člankov, zastavili raziskovalno vprašanje, kako ustvarjati in nadgrajevati trajnostno prihodnost $\mathrm{v}$ organizacijah?

Namen: Teoretična predstavitev Modela poslovne odličnosti EFQM in samoocenjevanja, poudarek na Ustvarjanju trajnostne prihodnosti pomena vodij organizacij in predstavitev okoljskih, družbenih in ekonomski učinkov.

Metoda: Pri raziskavi smo uporabili kvalitativno metodo, ki temelji na analitičnem preučevanju. Zbrali smo literaturo, članke in informacije ter jih pregledali in analizirali.

Rezultati: Z raziskavo smo ugotovili, da je za ustvarjanje trajnostne prihodnosti, potreben enakovreden poudarek na družbo, okolje in ekonomijo, ključna pa je podpora vrhnjega menedžmenta, ki vodi v poslovno odličnost organizacije.

Organizacija: Raziskava in študija različnih člankov nam daje informacije o pomenu vodilnih v organizaciji in strateški usmeritvi v trajnostno prihodnost.

Družba: Organizacija je tista, ki s svojim delovanjem v trajnostno prihodnost lahko največ naredi za družbo, okolje in svojo konkurenčno ter ekonomsko prednost.

Originalnost: V raziskavo so vključeni trije dejavniki, ki s pomočjo vodij in deležnikov vodijo v trajnostno prihodnost.

Omejitve/nadaljnje raziskovanje: Raziskovanje je bilo opravljeno na podlagi zbrane literature, člankov in informacij.
\end{abstract}

Ključne besede: organizacija, vodje, trajnostna prihodnost, okolje učinki, družbeni učinki, ekonomski učinki, Model odličnosti EFQM.

\section{Uvod}

Okoljski problemi (izumiranje živalskih in rastlinskih vrst, učinek tople grede, širjenje ozonske luknje, ipd.) in ekonomski problemi (finančne krize, brezposelnost, plačilna 
nedisciplina, ipd.) ter družbeni problemi (revščina, kršenje človekovih pravic, ipd.) zahtevajo, da spremenimo svoje vedenje, če želimo, da bodo imeli naši potomci enake možnosti za življenje in razvoj, kot smo jih imeli mi. To pomeni, da moramo začeti delovati v smeri trajnostnega razvoja. Trajnostni razvoj je razvoj današnje družbe, ki ne ovira sposobnosti razvoja družbe prihodnosti. Določajo ga ekonomski, družbeni in okoljski vidik.(Belz \& Bilharz, 2005, str. 2-3)

Organizacije se ves čas prilagajajo spremembam v okolju v katerem delujejo, saj nam je dobro znano, da so spremembe edina stalnica v prihodnosti. Okolje od organizacij pričakuje, da pri svojem delovanju poleg interesov lastnikov upoštevajo tudi druge interese, kot so zaposleni, kupci, dobavitelji in družba. $\mathrm{V}$ ta namen se je razvilo poročanje o družbeni odgovornosti, ki tako podjetja kot širšo javnost opozarjajo na svoje odgovorno ravnanje z zaposlenimi in okoljem.

Želja vsake sodobne organizacije je, da dosegajo in izboljšujejo svoje poslovne rezultate, na vseh področjih delovanja, saj se zavedajo, da je ravnovesje med gospodarskim napredkom, družbeno odgovornostjo in varovanjem okolja vodilo v konkurenčno prednost pred ostalimi.

\section{Teoretična izhodišča}

Odličnost $\mathrm{v}$ organizacijah pomeni izjemnost, preseganje pričakovanj vseh zainteresiranih strani, (zaposleni, kupci, dobavitelji in družba), v globalnem konkurenčnem okolju. Za konkurenčno prihodnost organizacije, razvoj strategij ter organizacijsko prilagoditev je bistveno razumevanje obstoječih prednosti ter področji izboljšav. Zaupanje v organizacijo ne temelji zgolj samo na finančnih rezultatih, ki so izkaz preteklega delovanja. Za pridobivanje zaupanja $v$ trajnost rezultatov pa so potrebni dokazi o tem, da je tisto, kar organizacija počne, dobro zasnovano, sistematično ter da se stalno pregleduje in izboljšuje. Obstaja več modelov poslovne odličnosti $\mathrm{v}$ svetu, $\mathrm{v}$ Evropi je najbolj razširjen model odličnosti EFQM. (Kern Pipan \& Skubic, 2006, str. 1-2)

Model EFQM je praktično orodje, ki organizacijam pomaga vzpostaviti sistem z merjenjem, kako daleč smo na poti k odličnosti, pomaga razumeti, kje so vrzeli in nakazuje rešitve. Temeljna načela, ki jih model podpira: osredotočenost na odjemalca, usmerjenost v rezultate, voditeljstvo in stanovitnost namena, upravljanje na podlagi procesov in dejstev, razvoj in vključevanje zaposlenih, stalno učenje, inoviranje in izboljševanje, razvijanje partnerstva in družbena odgovornost. (Model odličnosti EFQM v Kern Pipan \& Leon, str. 67)

Trajnostni razvoj pomeni povečanje blagostanja, in sicer odgovorno in uravnoteženo dviganje materialnega, socialnega in okoljskega blagostanja sedanje generacije, brez ogrožanja naslednje (Bertoncelj et al., 2015). Tak način organizacije nedvoumno vodi tudi v finančno uspešnost. Trajnostna strateška transformacija poslovanja je proces, ki ni enostaven, je pa nujen. Če se organizacija odloči za trajnostno prenovo poslovanja, mora trajnostne vidike 
delovanja vpeljati $\mathrm{v}$ vse procese poslovanja, določiti jasne cilje, izvedbene aktivnosti in kazalnike, s katerimi meri uspešnost. (Hren \& Bohorič, 2020, str. 40)

Nekateri od načinov, kako uresničujemo trajnostno strategijo oz. kateri so trajnostni izzivi, so (Rejc Buhovac, 2018, str. 36): vključevanje v krožno gospodarstvo (snovne tokove), trajnostni (zeleni) izdelki, logistika z nizkim ogljičnim odtisom, podpiranje pravične trgovine, domišljeno sponzoriranje, varna in ergonomična delovna mesta, vzpostavitev infrastrukture za spodbujanje lokalnih podjetnikov, transparentno trajnostno in poslovno komuniciranje, zaposlovanje lokalnih kadrov, donacije različnim lokalnim skupnostim.

Pri ustvarjanju trajnostne prihodnosti ima najpomembnejšo vlogo najvišje vodstvo organizacije, in sicer so njihove vloge naslednje (Rejc Buhovac, A., 2018, str. 46 - 50): kot pobudnik in vzornik, kot strateg, kot uresničevalec trajnostne poslovne strategije $\mathrm{v}$ dialogu z lastnikom: promotor trajnostnih priložnosti.

Podjetja, ki znajo izbrati prave ljudi in iz njih izluščiti največ, si priborijo enkratno konkurenčno prednost. Izdelke in storitve lahko namreč konkurenca zelo zlahka posnema. Uslužbencev in njihovega dela pa ni niti slučajno tako enostavno »posnemati«. Podjetje, ki je na področju izbire in razvoja kadrov maksimalno uspešno, je torej hkrati tudi podjetje, ki si gradi prednost, ki je konkurenčna podjetja ne bodo mogla zlahka posnemati.(Treven v Colarič, 2019, str. 262-263)

Odlične organizacije se ne osredotočijo le nase, vedno delajo tudi za svoje okolje in družbo kot celoto. Vsakodnevno in dolgoročno udejanjajo načela poslovne odličnosti in prispevajo k nadaljnjemu razvoju. Poslovna odličnost temelji na naslednjih načelih (Strategija poslovne odličnosti 2018-2030, 2017, str. 2): dodajanje vrednosti za odjemalce, ustvarjanje trajnostne prihodnosti, razvijanje sposobnosti organizacij, spodbujanje ustvarjalnosti in inovativnosti, vodenje $\mathrm{z}$ vizijo, navdihom, in integriteto, agilni menedžment, doseganje uspehov $\mathrm{z}$ nadarjenostjo zaposlenih in trajno ohranjanje rezultatov.

V našem članku se bomo osredotočili na načelo: Ustvarjanje trajnostne prihodnosti. Odlične organizacije z izboljševanjem uspešnosti svojega delovanja pozitivno vplivajo na svet okoli sebe, s tem pa tudi na gospodarske, okoljske in družbene razmere v skupnosti, s katerimi so v stiku (Model odličnosti EFQM, 2013, str. 5):

- zagotavljajo svojo prihodnost tako, da določijo in sporočajo osrednji namen, ki je temelj njihove celovite vizije, poslanstva, vrednot, etike in korporativnega vedenja;

- razumejo svoje ključne kompetence in kako lahko ustvarjajo skupno vrednost v korist širše družbe;

- vključujejo načela trajnostnega razvoja v svojo temeljno strategijo, verigo vrednosti in procesa oblikovanja ter zagotavljajo sredstva, potrebna za uresničenje teh ciljev;

- pri usklajevanju nasprotujočih si zahtev, s katerimi se soočajo, upoštevajo »ljudi, okolje in dobiček «; 
- spodbujajo svoje deležnike k sodelovanju pri družbeno koristnih dejavnostih;

- namenjajo sredstva za zadovoljevanje dolgoročnih potreb in ne le kratkoročnega dobička ter, kjer je relevantno, dosegajo in ohranjajo konkurenčnost;

- oblikujejo svoje portfelje izdelkov in storitev ter dejavno in odgovorno obvladujejo celoten življenjski cikel izdelkov;

- lahko dokažejo, da merijo in optimizirajo vpliv svojega delovanja, življenjskih ciklov izdelkov in storitev na javno zdravje, varnost in okolje;

- dejavno razvijajo gospodarske, okoljske in družbene standarde na svojem področju.

Name naloge je spoznati, kaj pomeni trajnostna prihodnost za organizacije, cilj pa je ugotoviti kako vpliva vpeljava trajnostne prihodnosti na razvoj organizacije in družbe.

\section{Metoda}

Na sliki 1 je prikazan teoretični model raziskave kjer so izpostavljeni ključni učinki, ki so pomembni za trajnostno prihodnost organizacije, to so okoljski, družbeni in ekonomski učinki.

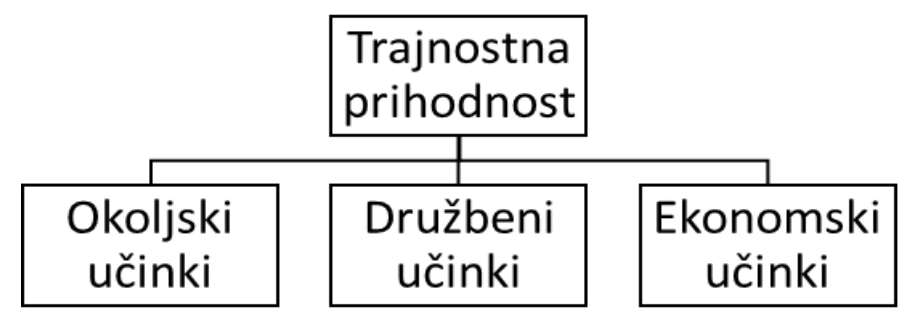

Slika 1. Teoretični model raziskave

Pri raziskavi smo uporabili kvalitativno metodo, ki temelji na analitičnem preučevanju. Zbrali smo literaturo, članke in informacije ter jih pregledali in analizirali. Kriterija za izbor člankov sta bila njihova strokovnost, ter čas nastanka, saj smo si želeli čim novejše vite literature, člankov. V tabeli 1 smo zapisali ključne besede iskanja po bazah podatkov. Gradiva smo iskali v elektronski bazi podatkov Google Učenjak, Digitalna knjižnica Slovenije (dlib) in na spletni strani Fakultete za organizacijske študije (FOŠ) Novo mesto v spletnih revijah Revija za Univerzalno odličnost, in sicer od oktobra do decembra 2020. Seznam pregledana in zbrana literatura je prikazana $\mathrm{v}$ tabeli 2.

Tabela 1. Seznam ključnih besed in baze podatkov

\begin{tabular}{ll}
\hline $\begin{array}{l}\text { Ključne besede iskanja v slovenskem in angleškem } \\
\text { jeziku }\end{array}$ & Baze podatkov \\
\hline $\begin{array}{l}\text { EFQM model (EFQM model), trajnostna prihodnost } \\
\text { (sustainble future), trajnostna strategija (sustainable }\end{array}$ in FOŠ Revija za Univerzalno odličnost \\
$\begin{array}{l}\text { strategy), trajnostni razvoj (sustainable development), } \\
\text { vodenje (leadership), organizacija (organization) }\end{array}$ \\
\hline
\end{tabular}


Marec 2021, leto / year 10, številka / number 1, str. / pp. 14-25.

Tabela 2. Seznam uporabljene literature

\begin{tabular}{|c|c|}
\hline Avtor (letnica) & Naslov \\
\hline Robnik, A. (2009) & Sektor IKT z roko v roki z drugimi sektorji za trajnejšo prihodnost. \\
\hline Ivančič, L. (2015) & Trajnostni razvoj, izobraževalni management kakovosti. \\
\hline Fink Babič, S. (2006) & Vloga inovativnosti pri trajnostnem razvoju \\
\hline Belak, T. (2016) & Koncept trajnostnega razvoja in povezava $\mathrm{z}$ gospodarskim razvojem \\
\hline Kmetec, A. (2016) & EFQM model in/ali družbena odgovornost \\
\hline Langerholc, M. (2016) & $\begin{array}{l}\text { Izboljšanje dimenzij voditeljstva in človeških virov v modelu poslovne odličnosti } \\
\text { EFQM }\end{array}$ \\
\hline $\begin{array}{l}\text { Bevc Šekoranja, B. } \\
(2016)\end{array}$ & $\begin{array}{l}\text { Uresničevanje načela trajnostnega razvoja v območjih varstva narave z aplikacijo } \\
\text { na prostoru ALP }\end{array}$ \\
\hline Žunič, A. (2017) & Vzgoja in izobraževanje za trajnostni razvoj na razredni stopnji osnovne šole \\
\hline Vavdi, M. (2015) & $\begin{array}{l}\text { Izvajanje kurikula okoljske vzgoje kot vzgoje in izobraževanja za trajnostni } \\
\text { razvoj v zadnjem triletju osnovne šole }\end{array}$ \\
\hline
\end{tabular}

V raziskovalnem delu članka smo uporabili preglednico ocen FOŠmeter poslovne odličnosti preglednica ocen, ki povzema rezultate samoocenitve matičnih organizacij udeležencev Poletne šole FOŠ »Poslovna odličnost« in sicer 20 za leto 2018 in 49 za leto 2020. Samoocenitev poslovne odličnosti je bila izvedena po metodologiji, ki jo je razvila Fakulteta za organizacijske študije v Novem mestu in temelji na modelu odličnosti EFQM. FOŠmeter poslovne odličnosti za vsakega od osmih gradnikov odličnosti podaja opise usmeritvenih trditev, pri čemer je bila za potrebe samoocenitve stopnja doseganja stanja vrednotena $\mathrm{v}$ razponu od 0 do 5 kot to predvideva metodologija modela CAF (Common Assesement Framework). (FOŠmeter poslovne odličnosti: Preglednica ocen)

\section{Rezultati in razprava}

\subsection{Raziskava gradnika Ustvarjanje trajnostne prihodnosti}

Skrb za okolje in trajnostni razvoj morajo biti visoko na seznamu prednostnih nalog vsake organizacije. Zavedanje, da je potrebno za zagotavljanje boljše dolgoročne prihodnosti, trajnostno delovanje organizacij, ki z okoljsko in družbeno odgovornostjo vodijo v konkurenčno in posledično finančno uspešnost. Ugotovili smo, da se morajo organizacije zavedati poslovnih priložnosti trajnostne naravnanosti, ključna vloga pri tem pa je podpora vrhnjega menedžmenta. V tabeli 3 so zbrane ključne ugotovitve avtorjev na temo ustvarjanje trajnostne prihodnosti. 
Revija za univerzalno odličnost / Journal of Universal Excellence,

GRADNIKI POSLOVNE ODLIČNOSTI

Marec 2021, leto / year 10, številka / number 1, str. / pp. 14-25.

Tabela 3. Pregled literature na temo ustvarjanja trajnostne prihodnosti Avtor (letnica) Ključne ugotovitve

Robnik, A. (2009)

Ivančič, L. (2015)

Fink Babič, S. (2006)

Belak, T. (2016)

Kmetec, A. (2016)

Langerholc, M. (2016)

Bevc Šekoranja B. (2016)

Žunič, A. (2017)

Vavdi, M. (2015)

Sektor IKT je z svojimi inovativnimi rešitvami in principi, izjemno pomemben samostojen sektor, v povezavi z drugimi sektorji pa se njegov pomen za trajnejši razvoj še poveča.

Za večjo konkurenčnost tako $v$ proizvodnji, kot pri storitveni dejavnosti je nujna

kakovost. Izobraževalni management zagotavlja kakovostne izobraževalne storitve po konkurenčnih cenah.

Pri doseganju trajnostnih načel, s poudarkom na okoljskem vidiku ima pomembno vlogo inovativnost

Ideja trajnostnega razvoja pomeni ohranjanje visokega nivoja gospodarske rasti in zaposlovanja, spodbujanje socialnega napredka ter ohranjanje naravnega okolja.

Na osnovi anketnega vprašalnika izvedena primerjalna analiza med vodstvom in delavci. Z njim so ugotavljali razlike med ocenjevanjem obeh ciljnih skupin. Na podlagi tega, so poskusili najti povezavo med EFQM modelom in družbeno odgovornostjo.

Vodstvo ima zelo velik vpliv na zaposlene. Najpomembnejša vloga vodstva je doseči

fleksibilnost, $s$ katero organizacija obvladuje spremembe. Pomembne so primerne motivacijske metode in priznanje, da so vsi zaposleni pomembni. Zaposleni želijo od vodstva pozitiven pristop, prepoznano inovativnost zaposlenih in občutek, da vsi delajo za isti cilj.

Socialni, politični in ekonomski dejavniki pomembno vplivajo na uresničevanje trajnostnega razvoja, saj se države z višjim BDP uspešneje bojujejo proti izgubi biotske raznovrstnosti.

V zadnjem desetletju se stanje vzgoje in izobraževanja za trajnostni razvoj v osnovnih šolah precej izboljšuje, čeprav je vsebin, vezanih na izobraževanje za trajnejši razvoj, malo.

Osnovne šole, ki so vključene v program Ekošole in uvajan predmet okoljska vzgoja, imajo več preučenih vsebin o trajnostni prihodnosti, kot šole, ki v ta program niso vključene.

Model EFQM organizacijam pomaga vzpostaviti sistem z merjenjem, kako daleč so na poti k odličnosti, pomaga razumeti, kje so vrzeli in nakazuje rešitve. V magistrski nalogi je Kmetec A. (2016, str. III, 103,104) izvedla raziskavo o vodenju podjetja, ki vključuje tako mnenja delavcev, kot vodstva. V raziskavi sta obe skupini odgovarjali na enak anketni vprašalnik. $\mathrm{Na}$ podlagi odgovorov je avtorica skušala najti povezavo med EFQM modelom in družbeno odgovornostjo $\mathrm{v}$ manjšem podjetju. $\mathrm{V}$ začetku postavljeno tezo, da bodo večja odstopanja $\mathrm{v}$ odgovorih med skupinami, je avtorica na koncu ovrgla, saj so bile le manjše razlike. Ugotovila je, da se EFQM model in družbena odgovornost v podjetju prepletata, če podjetje sledi etičnemu vodenju, ekonomskemu razvoju, izboljšanju kakovosti zaposlenih in družbe nasploh. (Kmetec A. 2016, str. III, 103,104)

Uporabnost modela EFQM je v svoji magistrski nalogi preverila tudi Langerholc M. Z njim je raziskala povezanost dejavnika »voditeljstvo« in »zaposleni«, ki sta ključna za dogajanje v vsaki organizaciji. Ugotovila je, da ima vodstvo zelo velik vpliv na zaposlene. Najpomembnejša vloga vodstva je doseči fleksibilnost, s katero organizacija obvladuje spremembe. Ostale, tudi pomembne pa so primerne motivacijske metode in priznanje, da so 
Marec 2021, leto / year 10, številka / number 1, str. / pp. 14-25.

vsi zaposleni pomembni. Zaposleni želijo od vodstva pozitiven pristop, prepoznano inovativnost zaposlenih in občutek, da vsi delajo za isti cilj. (Langerholc M. (2016, str. III, 103)

$\mathrm{Na}$ pot k odličnosti nas lahko privedejo le inovativni in izobraženi kadri. V prihodnosti bo stalno izobraževanje postalo del našega življenja, zato bi morala biti kakovost izobraževanja najpomembnejša. $\mathrm{V}$ zadnjem času smo priča velikim spremembam, v povezavi z trajnostnim razvojem tudi na področju izobraževanja odraslih. Za pridobljeno, čimbolj kakovostno znanje skrbijo managerji $\mathrm{v}$ izobraževalnih ustanovah skupaj $\mathrm{z}$ svojimi sodelavci. Ker je velika konkurenca na področju izobraževanja odraslih, bi moral biti glavni kriterij izbora prepoznana kakovost, ter posledično večja zasedenost. Žal temu ni tako in je mnogokrat pomembnejši dejavnik cena izobraževalnega programa (Ivančič L.,2015, str. 31, 37).

Ker svet stoji na mladih, je pomembno izobraziti in poučevati o trajnostnem razvoju že osnovnošolce. V mag nalogi Žunič A. ugotavlja, da se v zadnjem desetletju stanje vzgoje in izobraževanja za trajnostni razvoj v osnovnih šolah precej izboljšuje, je pa vsebin, vezanih na izobraževanje za trajnejši razvoj, malo. Zelo pomembno je izobraziti učitelje, da bodo čim bolj usposobljeni za poučevanje o trajnostnem načinu, da učenci od tega odnesejo največ in koristno uporabijo naprej v vsakdanjem življenju. (Žunič A.,2017, str.74)

Najpogostejši načini poučevanja vsebin okoljske vzgoje pri osnovnošolcih so razprave $\mathrm{v}$ razredu o okoljskih temah, dejavnosti $\mathrm{v}$ naravi ter pogovori o vsakodnevnih navadah, ki vplivajo na okolje. Vavdi M. ugotavlja, da imajo osnovne šole, ki so vključene v program Ekošole in uvajan predmet okoljska vzgoja, več preučenih vsebin o trajnostni prihodnosti, kot šole, ki v ta program niso vključene. Zaradi pozitivnega učinka bi bilo smiselno sodelovanje v programu Ekošole vseh šol v Sloveniji. (Vavdi M., 2015, str. III, 38, 39)

Kakšna bo naša prihodnost, se ne ve, je pa veliko odvisno od uravnoteženosti in harmonizacije tehnološke, okoljske, ekonomske in sociološke zrelosti vseh udeleženih $\mathrm{v}$ globalnem svetu. Pri tem bo sektor IKT (informacijske in komunikacijske tehnologije) z naprednimi in ekološko prijaznimi omrežji, obogatenimi storitvami in aplikacijami, sodobnimi poslovnimi modeli še izboljšal svojo veljavo, ter pripomogel k ekonomski in sociološki zrelosti družbe ter k trajnejši prihodnosti. (Robnik A., 2009, str. 263 - 269)

Pri doseganju trajnostnih načel, s poudarkom na okoljskem vidiku ima pomembno vlogo inovativnost. Kontinuirana potreba po inovaciji spodbuja ustvarjalnost, ki se kaže na trgu (višja kakovost, več novosti), v ekonomiji (svobodno podjetništvo, več možnosti za delo, izobrazba), kot tudi v politiki. Inovativna družba bo lažje reševala okoljske probleme in $\mathrm{z}$ svojim znanjem in sposobnostmi poiskala trajnostne rešitve. (Sonja Fink Babič S. 2006, str 314)

Nekateri zmotno mislijo, da je trajnostni razvoj le skrb za naravne vire. Ideja trajnostnega razvoja pomeni ohranjanje visokega nivoja gospodarske rasti in zaposlovanja, 
spodbujanje socialnega napredka ter ohranjanje naravnega okolja. Trajnostni razvoj narekuje smernice za zasnovo strategij trajnostne politike. Dobro bi bilo, da se vzpostavi sistem kazalnikov trajnostnega razvoja, ki bi omogočal nadzor in primerjavo med državami. $\mathrm{Na}$ takšen način bi lahko državam sporočili, na katerem področju trajnostnega razvoja zaostaja in kje so možnosti izboljšav. Države se zanimajo za trajnostni razvoj, kar se kaže v ponudbi in povpraševanju za evropska sredstva na področju ekologije in spodbujanja odpiranja delovnih mest. Po drugi strani pa uvajajo »ekološke« davke v skrbi za okolje, v katerem živimo. (Belak T.,2016, str. 57 - 58)

Koncept trajnostnega razvoja se kaže kot preplet materialnega, socialnega in okoljskega dejavnika, kar lahko vidimo tudi $\mathrm{v}$ boju proti izgubi biotske raznovrstnosti. Rezultati iz doktorske dizertacije so namreč pokazali, da delež, število in površina zavarovanih območij, niso odvisni le od biotske raznovrstnosti. Na uresničevanje trajnostnega razvoja pomembno vplivajo tudi socialni, politični in ekonomski dejavniki, saj se države z višjim BDP uspešneje bojujejo proti izgubi biotske raznovrstnosti. (Bevc Šekoranja B. 2016, str. VII, $275-280$ )

\subsection{Analiza gradnika Ustvarjanje trajnosten prihodnosti}

V tabeli 4 so predstavljeni rezultati ankete FOŠmeter poslovne odličnosti, za podgradnik Ustvarjanje trajnostne prihodnosti za leto 2018 in 2020. Anketiranci so najvišje ocenili, z povprečno oceno 4,30 prvi podgradnik, to je dejstvo da organizacije zagotavljajo prihodnost tako, da določijo in sporočajo osrednji namen, ki je temelj njihove celotne vizije, poslanstva, vrednot, etike in korporativnega vedenja. Iz tega sklepamo, da si vodstvo prizadeva postati boljši in uglednejši ter, da je usmeritev $\mathrm{v}$ trajnostno prihodnost vodilo $\mathrm{v}$ dolgoročno gospodarsko rast.

Drugi, šesti, sedmi in osmi podgradnik so anketiranci ocenili z povprečno oceno od 3,96 do 4,01. Iz tega sklepamo, da organizacije dobro vzdržujejo zastavljene cilje.

Tudi tretji podgradnik je bil za leto 2018 in 2020 ocenjen z povprečno oceno 4,00. Vendar smo ga izpostavili, ker je v letu 2018 iz ocene 4,15 padel na 3,94 v letu 2020. Menimo, da je to področje, na katerem bi morale organizacije pregledati temeljno strategijo, verigo vrednosti in procese oblikovanja ter zagotoviti potrebna sredstva za uresničitev ciljev. Pri četrtem in petem podgradniku, organizacije niso ne napredovale, ne nazadovale. Povprečna vrednost za oba podgradnika je 3,78 tako za leto 2018, kot 2020. Tukaj vidimo priložnost, da organizacije spodbudijo svoje deležnike $\mathrm{k}$ sodelovanju pri družbeno koristnih dejavnostih ter pri usklajevanju nasprotujočih si zahtev upoštevajo »ljudi, okolje in dobiček«. Ostal nam je še najslabše ocenjen, deveti podgradnik, kjer naj bi organizacije dejavno razvijale gospodarske, okoljske in družbene standarde na svojem področju. Anketiranci so tukaj prepoznali pomanjkljivost $\mathrm{v}$ organizacijah. Ocena 3,70 iz leta 2018, je padla na 3,51 v letu 2020. Menimo, da imajo organizacije na voljo ogromno standardov, ki jim pomagajo pri oblikovanju strategij in zato ni potrebe, da razvijajo svoje. 
Marec 2021, leto / year 10, številka / number 1, str. / pp. 14-25.

Ob pregledu povprečnih vrednosti za leto 2018 in 2020, smo opazili, da ni bistvenih razlik v rezultatih. Povprečna ocena za leto 2018 za celoten gradnik je 3,94 za leto 2020 pa 3,93. Zato predvidevamo, da organizacije nadaljujejo svojo uspešnost $\mathrm{v}$ delovanju in $\mathrm{s}$ tem pozitivno vplivajo na ekonomijo, okolje in družbo.

Tabela 4. FOŠmeter ocena poslovne odličnosti: Ustvarjanje trajnostne prihodnosti za leto 2018 in 2020

Št. Ustvarjanje trajnostne prihodnosti za leto 2018 in 2020

\begin{tabular}{lll}
2018 & 2020 & \multicolumn{2}{l}{ SKUPAJ } \\
& & 2018 in \\
& & 2020 \\
4,35 & 4,29 & 4,30
\end{tabular}

1. zagotavljajo svojo prihodnost tako, da določijo in sporočajo osrednji namen, ki je temelj njihove celovite vizije, poslanstva, vrednot, etike in korporativnega vedenja;

2. razumejo svoje ključne kompetence in kako lahko ustvarjajo skupno $\quad 3,95 \quad 4,04 \quad 4,01$ vrednost v korist širše družbe

3. vključujejo načela trajnostnega razvoja v svojo temeljno strategijo, $4,15 \quad 3,94 \quad 4,00$ verigo vrednosti in procesa oblikovanja ter zagotavljajo sredstva, potrebna za uresničenje teh ciljev;

\begin{tabular}{lllllll}
\hline 4. & pri usklajevanju nasprotujočih si zahtev, s katerimi se soočajo, & 3,75 & 3,80 & 3,78
\end{tabular} upoštevajo »ljudi, okolje in dobiček«;

$\begin{array}{llllll}\text { 5. } & \text { spodbujajo svoje deležnike } \mathrm{k} \text { sodelovanju pri družbeno koristnih } & 3,80 & 3,78 & 3,78\end{array}$ dejavnostih;

6. namenjajo sredstva za zadovoljevanje dolgoročnih potreb in ne le $\quad 4,10 \quad 3,96 \quad 4,00$ kratkoročnega dobička ter, kjer je relevantno, dosegajo in ohranjajo konkurenčnost;

7. oblikujejo svoje portfelje izdelkov in storitev ter dejavno in $3,85 \quad 4,0 \quad 3,96$ odgovorno obvladujejo celoten življenjski cikel izdelkov;

8. lahko dokažejo, da merijo in optimizirajo vpliv svojega delovanja, $3,80 \quad 4,10 \quad 4,01$ življenjskih ciklov izdelkov in storitev na javno zdravje, varnost in okolje;

9. dejavno razvijajo gospodarske, okoljske in družbene standarde na $\quad \begin{array}{llll}3,70 & 3,51 & 3,57\end{array}$ svojem področju. 


\section{Zaključek}

V svetu obstaja več modelov poslovne odličnosti organizacij, v Evropi je najbolj razširjen model odličnosti EFQM. Model odličnosti EFQM je kompleksno analitično managersko orodje, ki omogoča realno oceno organizacije, kako dobra je, daje celovit okvir za razvoj sistema vodenja, prikaže priložnosti izboljševanja, spodbuja izmenjavo dobrih praks in stalno kritično preverjajo svoje dosežke, se učijo in izboljšujejo, se hitro odzivajo na spremembe potreb in pričakovanj vseh udeleženih strani, razvijajo partnerstva in prispevajo k družbenemu razvoju. Odličnost je odvisna od uravnoteženja in zadovoljevanja potreb vseh udeležencev. Vodenje in obnašanje vodij najbolj pokaže, kakšne namene ima organizacija. Odlične vodje organizacij načrtujejo jasne usmeritve, vzpostavljajo vrednote, etiko in s tem kulturo, da vzpodbujajo druge zaposlene k odličnosti.

Skrb za okolje in trajnostni razvoj morajo biti visoko na seznamu prednostnih nalog vsake organizacije. Zavedanje, da je potrebno za zagotavljanje boljše dolgoročne prihodnosti, trajnostno delovanje organizacij, ki $\mathrm{z}$ okoljsko in družbeno odgovornostjo vodijo $\mathrm{v}$ konkurenčno in posledično finančno uspešnost. Ugotovili smo, da se morajo organizacije zavedati poslovnih priložnosti trajnostne naravnanosti, ključno vloga pri tem pa je podpora vrhnjega menedžmenta.

Za takšno miselnost je zelo pomembno izobraževanje o trajnostni prihodnosti že od osnovne šole dalje, da učenci preučeno snov koristno uporabijo naprej v vsakdanjem življenju. Saj so vsi vodje nekoč bili osnovnošolci.

Organizacije lahko z svojimi vodji analizirajo našo raziskavo in skupaj ugotovijo, ali pri vodenju upoštevajo vse tri dejavnike trajnostne prihodnosti, torej človeka, okolje in dobiček. V nadaljevanju raziskovanja, bi se lahko razširili na organizacijo, ki še nima vpeljanih standardov odličnosti ter raziskali vloge različnih skupin pri ustvarjanju prihodnosti. Smiselna bi bila tudi primerjava uspešnosti organizacije, ki imajo vpeljane standarde odličnosti, z tistimi, ki jih nimajo.

\section{Reference}

1. Belak, T. (2016) Koncept trajnostnega razvoja in povezava z gospodarskim razvojem Magistrsko delo. Maribor: Univerza v Mariboru. Ekonomsko poslovna fakulteta Maribor.

2. Belz, F.M., \& Bilharz, M. (2005). Nachhaltiger Konsum: Zentrale Herausforderung fur moderne Verbraucher Politik. Consumer Science, 1, str. 2-3. Pridobljeno na http://www.keypointer.de/ fileadmin/media/Belz-Bilharz_2005_DB1_N-Konsum-Verbraucherpolitik.pdf

3. Bertoncelj, A. \& Bervar, M. \& Meško, M. \& Naraločnik, A. \& Nastav, B. \& Roblek, V., \& Trnavčević, A., (2015) Trajnostni razvoj: ekonomski, družbeni in okoljski vidiki. Ljubljana: IUS Sofware, GV Založba. 
Marec 2021, leto / year 10, številka / number 1, str. / pp. 14-25.

4. Bevc Šekoranja B. (2016) Uresničevanje načela trajnostnega razvoja v območjih varstva narave za aplikacijo na prostoru ALP Doktorska dizertacija. Ljubljana: Univerza v Ljubljani. Fakulteta za gradbeništvo in geodezijo

5. Colarič G. (2019). Model dejavnikov trajnega doseganja odličnih rezultatov. Revija za univerzalno odličnost, jun. 2019, letnik 8, št. 3., str. 259-270.

6. Fink Babič S. (2006) Vloga inovativnosti pri trajnostnem razvoju. Organizacija, letnik 39, št. 5, str. 314-320.

7. Hren, A. \& Bohorič P. (2020). Trajnostna transformacija poslovanja ni več izbira, temveč nuja. Podjetniški portal. Pridobljeno na https://www.podjetniski-portal.si/uploads/gradiva/Trajnostni _razvoj/Trajnostna_transformacija_slowood_clanek.pdf

8. Ivančič L. (2015) Trajnostni razvoj, izobraževalni management kakovosti Zbornik 12. festivala raziskovanja ekonomije in managementa Koper Pridobljeno na http://www.fmkp.si/zalozba/ISBN/978-961-266-185-4/prispevki/004.pdf

9. Kern Pipan K. \& Skubic I. (2006). Modeli odličnosti kot sodobno orodje za uveljavljanje učinkovitosti in uspešnosti. Pridobljeno na https://www.podjetniski-portal.si/uploads/gradiva/ poslovna_odlicnost/gradiva_pod_poslovno_odlinost/35_kern_pipan-skubic-otocec-2006-25-406.pdf

10. Kern Pipan, K. \& Leon, L., Ministrstvo za šolstvo, znanost in šport, Urad za meroslovje (MIRS). (2020). Pristopi za doseganje odličnosti - modela EFQM, CAF ter pilotni project prspo. Podjetniški portal. Pridobljeno na https://www.podjetniski portal.si/uploads/ gradiva/poslovna _odlicnost/gradiva_pod_poslovno_odlinost/46_pristopi.pdf

11. Kmetec A. (2016) EFQM model in/ali družbena odgovornost Magistrsko delo. Maribor: Univerza v Mariboru. Fakulteta za logistiko Maribor.

12. Langerholc, M. (2016) Izboljšanje dimenzij voditeljstva in človeških virov v modelu poslovne odličnosti EFQM Magistrsko delo. Maribor: Univerza v Mariboru. Fakulteta za organizacijske vede.

13. MIRS, Strategija poslovne odličnosti 2018-2030. (2017). Ljubljana: Urad RS za meroslovje. MIRS, EFQM model odličnosti. (2012). Ljubljana: Urad RS za meroslovje.

14. EFQM Leading Excellence 2012. (2013). Model odličnosti EFQM (brošura). SPIRIT Slovenija, javna agencija.

15. Rejc Buhovac, A., in drugi (2018). Trajnostne poslovne strategije in trajnostni poslovni modeli v slovenski praksi (priročnik). SPIRIT Slovenija, javna agencija.

16. Robnik A. (2009) Sektor IKT z roko v roki z drugimi sektorji za trajnejšo prihodnost Elektrotehniški vestnik, letnik 78, št. 5., str. 263-269. Pridobljeno na https://ev.fe.uni-lj.si/52011/SRobnik.pdf

17. Vavdi, M. (2015) Izvajanje kurikula okoljske vzgoje kot vzgoje in izobraževanja za trajnostni razvoj v zadnjem triletju osnovne šole Magistrsko delo. Maribor: Univerza v Mariboru. Fakulteta za naravoslovje in matematiko.

18. Žunič, A. (2017) Vzgoja in izobraževanje za trajnostni razvoj na razredni stopnji osnovne šole Magistrsko delo. Maribor: Univerza v Mariboru. Pedagoška fakulteta.

19. Interno gradivo: FOŠmeter poslovne odličnosti: Preglednica ocen 
Polona Prosen je diplomirala na Zdravstveni fakulteti v Ljubljani, smer Sanitarno inženirstvo. Zaposlila se je v farmacevtskem podjetju, sedaj šolanje ob delu nadaljuje na Fakulteti za organizacijske študije v Novem mestu.

$* * *$

Janja Gornik je diplomirala na Biotehniški fakulteti v Ljubljani, smer Hortikultura. Zaposlila se je v farmacevtskem podjetju, sedaj šolanje ob delu nadaljuje na Fakulteti za organizacijske študije v Novem mestu.

$* * *$

\section{Abstract: \\ Creating a Sustainable Future}

Research Question: In the research, with the help of selected articles, we asked a research question, how to create and upgrade a sustainable future in organisation

Purpose: Teoretical presentation of the EFQM Bussines Excellence Model and self-assessment emphasis on Creating sustainable future of importance for leaders of organisations and presentation of environmental, social and economic effects.

Method: In the research, we used a qualitative method based on analythical study. We collected litherature, articles, and information and reviewed and analyzed them.

Results: The research found that creating a sustainable future requires an equal emphasis on the social, enviroment and economy, and the key is the support of top management, which leads to the business excellence of the organization.

Organization: Research and study of various articles gives us information about the inportance of leaders in the organization and strategic orientation towards a sustainable future.

Society: The organization is the one that can do the most for the social environment and its competitive and economic advantage through its activities for a sustainable future.

Originality: The research includes three factors that, with the help of leaders and stakeholders, lead to a sustainable future.

Limitations/Future Research: The research was conducted on the basis of collected literature, articles and information.

Keywords: organization, leaders, sustainable future, environmental effects, social effects.

Copyright (c) Polona PROSEN, Janja GORNIK

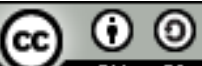

Creative Commons License

This work is licensed under a Creative Commons Attribution-ShareAlike 4.0 International License 